\title{
Resistance to reinfection in chinook salmon Oncorhynchus tshawytscha to Loma salmonae (Microsporidia)
}

\author{
M. L. Kent ${ }^{1, *}$, S. C. Dawe ${ }^{1}$, D. J. Speare ${ }^{2}$ \\ ${ }^{1}$ Fisheries and Oceans Canada, Pacific Biological Station, Nanaimo, British Columbia V9R 5K6, Canada \\ ${ }^{2}$ Department of Pathology and Microbiology, Atlantic Veterinary College, University of Prince Edward Island, \\ Charlottetown, Prince Edward Island, Canada
}

\begin{abstract}
Chinook salmon Oncorhynchus tshawytscha were experimentally infected per os with Loma salmonae and held in flow-through seawater tanks at 12 to $14^{\circ} \mathrm{C}$. The fish exhibited $100 \%$ infection when first examined at 7 wk post initial exposure (p.e.), and by 20 wk p.e. they had completely recovered from gill infections. The recovered fish were then re-exposed the following week. All of these fish showed strong protection to new $L$. salmonae infections, while naive fish exposed to the same inoculum developed the infection. Most of the re-exposed fish exhibited a few free spores or spores within phagocytes in the kidney interstitium at 20 to $29 \mathrm{wk} \mathrm{p.e.,} \mathrm{but} \mathrm{xenomas} \mathrm{were} \mathrm{not} \mathrm{detected} \mathrm{in}$ either the gills or visceral organs. The kidney is the primary site of reticulo-endothelial activity, and thus these spores were likely deposited in the kidney by entrapment by fixed macrophages. It is possible that these spores provide immunologic stimuli to reinforce the resistance to new $L$. salmonae infections.
\end{abstract}

KEY WORDS: Loma Oncorhynchus $\cdot$ Resistance

\section{INTRODUCTION}

Loma salmonae (Microsporidia) has caused gill disease in Pacific salmon species and rainbow trout Oncorhynchus spp. reared in freshwater hatcheries (Hauck 1984, Markey et al. 1994, Bruno et al. 1995) and in seawater netpens (Kent et al. 1989, Speare et al. 1989, Kent \& Poppe 1998). In seawater netpens, the parasite is most problematic in chinook salmon $O$. tshawytscha. One potential approach to control the disease would be to develop an effective vaccine. Speare et al. (1998b) demonstrated that rainbow trout held in fresh water that were experimentally infected with $L$. salmonae and then allowed to resolve infections were resistant to reinfection, indicating that salmonids can develop immunity to this parasite. Other salmonid species have also been shown to develop immunity to microsporidia; Awakura (1974) reported

\footnotetext{
-E-mail: kentm@dfo-mpo.gc.ca
}

that rainbow trout Oncorhynchus mykiss showed strong resistance to reinfection of the skeletal muscle by Microsporidium takedai.

As Loma salmonae is most pathogenic to chinook salmon reared in seawater netpens, we conducted a study similar to that of Speare et al. (1998a,b) using chinook salmon maintained in sea water to determine if this host species under these conditions also could develop immunity to L. salmonae.

\section{MATERIALS AND METHODS}

Heavily infected gills from a population of chinook salmon maintained at our facility were scraped with a scalpel blade to remove the tissue from the gill arch. This material was diluted 50:50 (v/v) with Hank's buffered saline solution and then thoroughly homogenized with a Polytron generator (Brinkmann Instruments Co., Rexdale, Ontario, Canada). This inoculum 
was diluted another $75 \%$ with chilled fresh water at time of intubation to obtain the appropriate spore dosage.

A total of 139 chinook salmon (avg. wt $250 \mathrm{~g}$ ) were experimentally infected per os by anesthetizing the fish with MS-222 and intubating each fish with $0.1 \mathrm{ml}$ inoculum (= ca $4.5 \times 10^{5}$ spores fish $\left.^{-1}\right)$. Exposed fish and uninfected (control) stock were held in running seawater tanks at 12 to $15^{\circ} \mathrm{C}$. The exposed fish were then divided equally into $725 \mathrm{l}$ tanks. Fish were fed daily with a commercial diet. Fish were reexposed to Loma salmonae as described above at $21 \mathrm{wk}$ after initial exposure. To reduce densities of the remaining fish, they were divided equally into 3 tanks. A control group of 8 naive fish from the same population were also exposed and maintained in a separate tank under identical conditions.

Gill samples of the exposed fish were collected and examined periodically by wet mounts and by histology throughout the study to determine the prevalence, onset of infection, and time at which fish recovered the infection (see Table 1 in 'Results'). In addition, kidneys from the samples collected at 20 wk and thereafter were examined by Gram stains and histology to detect Renibacterium salmonimarum infections, which is common in chinook salmon in British Columbia. Histological sections of selected kidneys in which spores of Loma salmonae were detected in Gram-stained imprints were also examined using a monoclonal antibody. Sections were treated with the spore wallspecific monoclonal antibody $4 \mathrm{HB}$ as described by Speare et al. (1998c), except that some representative slides were not counter-stained with hematoxylin.

\section{RESULTS}

A prevalence of $100 \%$ infection by Loma salmonae was observed in the experimentally infected fish al $7 \mathrm{wk}$ post initial exposure (p.e.), and the fish had essentially recovered from the active infection (as indicated by the presence of intact xenomas) by 20 wk p.e. (Table 1). None of the fish showed xenomas in the gills when examined at $29 \mathrm{wk}$, which was $8 \mathrm{wk}$ after reexposure. In contrast, all the control (naive) fish that were examined at this time were heavily infected.

Recovering fish exhibited multiple focal areas of chronic perivasculitis in the gill lamellae identical to those reported previously (Kent et al. 1989, 1995, Speare et al. 1989, Shaw et al. 1998), in which spores were occasionally observed in phagocytes.
A few of the apparently healthy fish that were sampled throughout the study also exhibited multiple granulomas in the kidney consistent with bacterial kidney disease, caused by Renibacterium salmonimarum, and these fish also exhibited the causative bacterium in Gram stains of kidney tissue (Table 1). These fish were also resistant to reinfection when examined at 29 wk p.e. Gram stains of the kidneys of several fish also revealed a few free spores of Loma salmonae (Table 1; Fig. 1). Routine histology of these kidneys revealed neither spores nor xenomas, but sections from the same kidneys treated with the spore-specific monoclonal antibody revealed free spores and, more rarely,

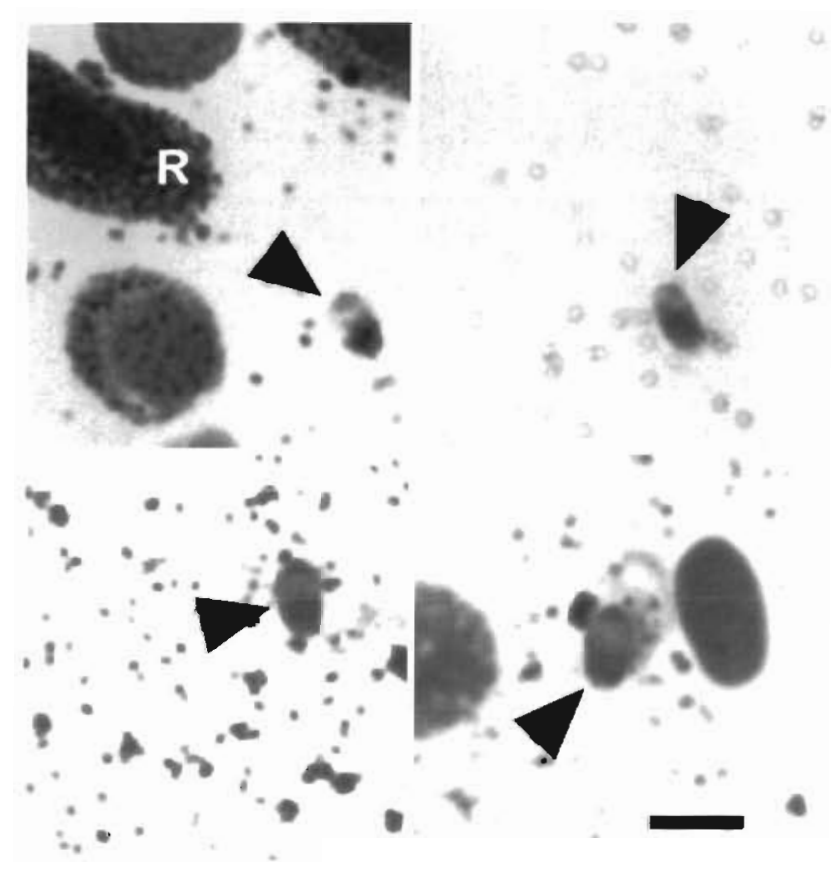

Fig. 1. Oncorhynchus tshawytscha. Free spores in Gram stain of kidney. Arrowheads $=$ spores. $\mathrm{R}=$ red blood cell. Scale bar $=5 \mu \mathrm{m}$ 


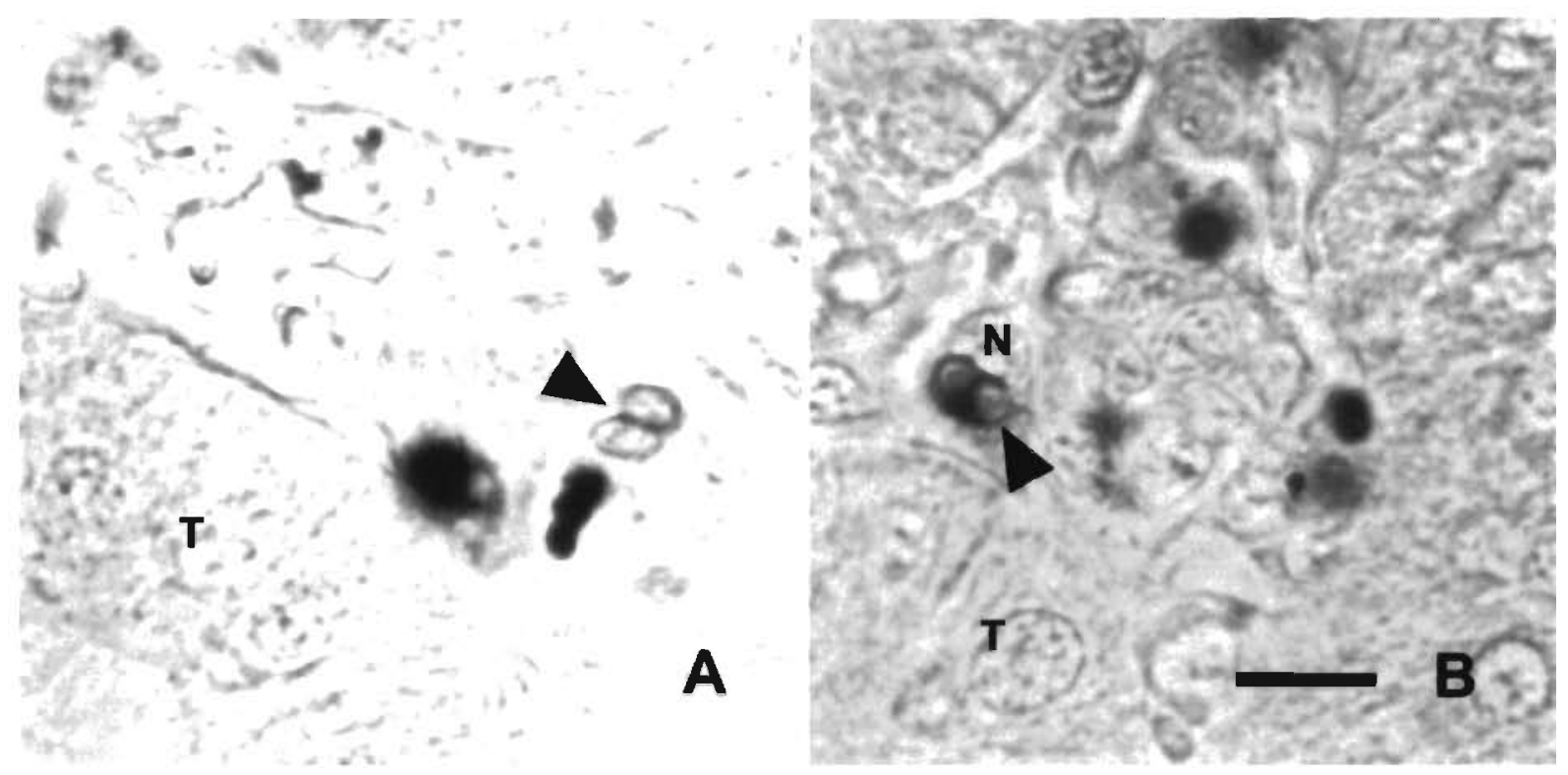

Fig. 2. Oncorhynchus tshawytscha. Kidney tissue sections stained with diamino-benidine chromogen lable monoclonal antibody to spore walls. $T=$ renal tubule. Scale bar $=10 \mu \mathrm{m}$. (A) Two free spores in interstitium. (B) Two spores in cross-section within a macrophage. $\mathrm{N}$ = nucleus of macrophage

spores within phagocytes in the kidney interstitium (Fig. 2). These spores were most evident in sections that were not counterstained with hematoxylin

A total of 19 fish died between 6 and 20 wk p.e. Of these fish, most died from bacterial kidney disease, exhibiting skin lesions, pallor of the gills indicating anemia and macroscopic granulomas in the kidney and other visceral organs. In addition, Gram stains of the kidneys of these fish revealed massive numbers of the bacterium. After 7 wk most of these fish also had Loma salmonae infections.

\section{DISCUSSION}

Our study concurred with that of Speare et al. (1998b) with rainbow trout in that fish that have recovered from active Loma salmonae infections show strong protection to reinfection. However, rainbow trout appear to recover faster than chinook based on the experiments conducted by Speare et al. (1998a,b). They found that rainbow trout recovered from active infections of $L$. salmonae infections by about $10 \mathrm{wk}$, whereas the xenomas were readily detected in the chinook salmon in our study at $14 \mathrm{wk}$ and were still detected in 1 of $10 \mathrm{f}$ :sh at $21 \mathrm{wk}$ p.e. Speare et al. (1998b) found that rainbow trout were resistant to reinfection when re-exposed at 24 and $36 \mathrm{wk}$ after initial exposure. This resistance to infection persisted for up to a year, with repeated exposures every 3 mo during this year (D. Speare unpubl. data). Beaman (1998) found that rainbow trout initially exposed to $L$. salmonae at low temperatures $\left(5\right.$ or $7^{\circ} \mathrm{C}$ ) or at high temperature $\left(21^{\circ} \mathrm{C}\right)$ did not develop xenomas, but were still protected following re-exposure at $15^{\circ} \mathrm{C}$.

Interestingly, while the infections in the chinook salmon had essentially resolved by $20 \mathrm{wk}$, spores of Loma salmonae were detected in the kidney of several fish at 29 wk p.e. This organ is the primary site of reticulo-endothelial activity, and thus these spores were likely deposited in the kidney by entrapment by fixed macrophages. It is possible that these spores provide immunologic stimuli to reinforce the resistance to new L. salmonae infections.

As suggested by Speare et al. (1998b) for rainbow trout, the present study suggests that a vaccine for Loma salmonae would be feasible. Our future experiments include determining how long this resistance and free spores in the kidney persist in recovered salmon.

Acknowledgements. We are indebted to Joanne Daley for preparation of monoclonal antibody-stained sections. Funding for this study was provided by NSERC Strategic Grant no 582073

\section{LITERATURE CITED}

Awakura $T$ (1974) Studies on the microsporidian infection in salmonid fishes. Sci Rep Hokkaido Fish Hatchery 29:1-96 Beaman HJ (1998) The regulatory effects of water temperature on Loma salmonae (Microspora) development in rainbow trout (Oncorhynchus mykiss). MSc thesis, Atlantic 
Veterinary College, Charlettown, Prince Edward Island, Canada

Bruno DW, Collins RO, Morrison CM (1995) The occurrence of Loma salmonae (Protozoa: Microspora) in farmed rainbow trout, Oncorhynchus mykiss Walbaum, in Scotland. Aquaculture 133:341-344

Hauck AK (1984) A mortality and associated tissue reactions of chinook salmon, Oncorhynchus tshawytscha (Walbaum), caused by the microsporidan Loma sp. J. Fish Dis $7: 217-229$

Kent ML, Poppe TT (1998) Diseases of seawater netpen reared salmonid fishes. Department of Fisheries and Oceans, Pacific Biological Station, Nanaimo, British Columbia, Canada

Kent ML, Elliott DG, Groff JM, Hedrick RP (1989) Loma salmonae (Protozoa: Microspora) infections in seawater reared coho salmon Oncorhynchus kisutch. Aquaculture 80:211-222

Kent ML, Dawe SC, Speare DJ (1995) Transmission of Loma salmonae (Microsporea) to chinook salmon in sea water. Can Vet J 36:98-101

Markey PT, Blazer VS, Ewing MS, Kocan KM (1994) Loma sp.

Editorial responsibility: Wolfgang Körting,

Hannover, Germany in salmonids from the Eastern United States: associated lesions in rainbow trout. J Aquat Anim Health 6:318-328

Shaw RW, Kent ML, Adamson ML (1998). Modes of transmission of Loma salmonae (Microsporea). Dis Aquat Org 33: $151-156$

Speare DJ, Brackett J, Ferguson HW (1989) Sequential pathology of the gills of coho salmon with a combined diatom and microsporidian gill infection. Can Vet J 30:571-575

Speare DJ, Arsenault GJ, Tech E, Boute MA (1998a) Evaluátion of rainbow trout as a model species for studying the pathogenesis of the branchial microsporidian Loma salmonae. Contemp. Top Lab Anim Sci 37:55-58

Speare DJ, Beaman HJ, Jones SRM, Markham RJF, Arsenault GJ (1998b) Induced resistance of rainbow trout to gill disease associated with the microsporidian gill parasite Loma salmonae. J Fish Dis 21:93-100

Speare DJ, Daley J, Markham RJF, Sheppard J, Beaman HJ, Sanchez JG (1998c) Loma salmonae-associated growth rate suppression in rainbow trout, Oncorhynchus mykiss (Walbaum), occurs during early onset xenoma dissolution as determined by in situ hybridization and immunohistochemistry. J Fish Dis 21:345-354

Submitted: February 16, 1999; Accepted: May 25, 1999 Proofs received from author(s): August 3, 1999 